\title{
Emotion as a function of the labeling of interruption-produced arousal*
}

\author{
P. S. FRY and D. G. OGSTON \\ The University of Calgary, Calgary, Alta., Canada
}

The experiment investigated the hypothesis that arousal elicited by interrupting a well-organized response pattern can be differentially manipulated, via confederate-provided cognitions, to be experienced as anger and euphoria. Twenty-five female Ss were individually coached to assemble the game Instant Insanity correctly. Each $S$ played with the game until an organized soluation pattern was established. Subsequently, they were unknowingly exposed to an insolvable version of the game. Upon the occurrence of a criterion acceleration of heart rate (arousal), a confederate was unobtrusively signaled to perform either a euphoric or angry routine. Postexperimental self-ratings indicated that aroused Ss were generally more susceptible to the confederate's expressed mood.

In recent years, the relationship between cognitive and physiological determinants of emotion has been the subject of an increasing number of investigations. Schachter (1964) has proposed that an emotional state may be considered a function of physiological excitation or arousal and of a cognition appropriate to this state of arousal. Available cognitions determine whether a state of physiological arousal is labeled "anger," "euphoria," or whatever.

Mandler (1964) contends that the interruption of a planned activity leads to the visceral precondition (physiological arousal) for emotional behavior. The exact nature of the emotion will be determined by the specific occasions (environmental cues) that accompany the interruption or inhibition of one's intention or plans. Mandler thus relates a day-to-day behavioral condition to cognitive determinants of emotion. The present study was conceived to investigate the proposition that arousal resulting from the interruption of an organized response is amenable to the manipulations of cognitive appraisal. SUBJECTS

Twenty-five student nurses, median age being 19 years, served as the Ss of the experiment. All were paid $\$ 1.50$ per hour, plus transportation costs to the laboratory.

\section{PROCEDURE}

The game Instant Insanity was used to establish an organized response pattern. The requirements of the game are such that solving the puzzle requires an organized sequential plan. While the game is known to be difficult for most people, it was modified so that a solution was

\footnotetext{
*Support for the study was given to the senior author by the University Research Grants Committee.
}

relatively simple. The Ss were informed that the purpose of the study was to investigate the influence of cognitive rehearsal on learning. Each $\mathrm{S}$ was seated in a one-way-vision room, introduced to the other female $S$ (confederate), fitted with heart-rate electrodes, and given a description of the purpose of the study.

The $S$ and confederate were left alone in the chamber for $2 \mathrm{~min}$ to permit habituation to the surroundings and to allow the physiological indices to baseline. The modified game was then introduced to them. They were coached by $E$ until they had completed one correct solution, following which they were left to practice with the game until they achieved the criterion of four successive correct completions. $E$ then entered the chamber, removed the modified game, and directed $S$ and the confederate to "rehearse in their minds" and "imagine" the solution of the game. Four minutes later, the original game was, unknown to $S$, substituted for the modified game. Each $S$ was asked to demonstrate that she remembered how to achieve a solution. The modified game was different from the original game in that the fourth and last block in the series had had one color panel changed to permit an easy solution. Consequently, practice with the original game was interrupted when $S$ attempted to apply rules learned with the modified game to the original game. This inability to implement the solution with the original game constituted the interruption of an organized response sequence for the purpose of the experiment. Ss in control groups were given the modified game to assemble following the rehearsal phase.

Arousal was defined as a 12-bpm increase of heart rate during the experience with the original game. Upon its occurrence, the confederate was unobtrusively signaled to commence her routine. The confederate either became euphoric or angry on the basis of the signal received from $E$. While euphoric, she made comical comments about the game, played with its blocks in a child-like manner, persuaded the $S$ to play $X_{s}$ and $O s$, and engaged the $S$ in girl talk. When angry, she made querulous comments about the game, drummed her fingers, slammed the blocks on the table, and generally glowered through the experience.

$$
\text { MEASURES }
$$

Immediately following the experiment, the $\mathrm{Ss}$ were given a 20-item questionnaire, imbedded in which were two 5-point rating scales of experienced feelings such as rated happiness and irritation. In addition, the questionnaire queried the S's prior experience with Instant Insanity and perceived difficulty with Instant Insanity and general impression of the experiment.

\section{RESULTS}

The central hypothesis of the study was that Ss experiencing arousal as a consequence of interruption would be more susceptible to the confederate's routine than the nonaroused Ss. Two-way analyses of variance were conducted for the Experimental Conditions by Confederate routines on each of the following criterion questions:

(3) How good or happy would you say you feel at present?

(12) How irritated, angry, or annoyed would you say you feel at present?

(The rating scale was: (1) Not at all (2) A little (3) Quite angry (4) Very angry (5) Extremely angry.)

Table 1 summarizes the results of the two analyses. Aroused and nonaroused Ss show no pronounced differences in their mean ratings of happiness after being exposed to a euphoric model. However, when exposed to an angry model, aroused Ss rate themselves significantly less happy than the nonaroused Ss $(F=2.177$, $\mathrm{p}<.06$ ). Mean ratings of irritation show the opposite effect. Under aroused conditions, Ss exposed to an angry model rate themselves more irritated than nonaroused Ss $(\mathrm{F}=2.867, \mathrm{p}<.05)$. The interaction of the two conditions is significant at the .06 level $(F=4.01)$. An examination of the mean "happiness" and "irritation" ratings shows that the anger induction was quite influential. The effect of the euphoria induction 
Table 1

Mean of Mood Postexperimental Ratings

\begin{tabular}{|c|c|c|c|c|}
\hline \multirow[b]{2}{*}{$\begin{array}{l}\text { Confederate } \\
\text { Routine }\end{array}$} & \multicolumn{2}{|c|}{ "Happiness" } & \multicolumn{2}{|c|}{ "Irritation" } \\
\hline & $\begin{array}{c}\text { Aroused } \\
\text { M }\end{array}$ & $\begin{array}{c}\text { Nonaroused } \\
M\end{array}$ & $\begin{array}{c}\text { Aroused } \\
\mathbf{M}\end{array}$ & $\begin{array}{c}\text { Nonaroused } \\
M\end{array}$ \\
\hline $\begin{array}{l}\text { Euphoric } \\
\text { Angry }\end{array}$ & $\begin{array}{l}2.50 \\
2.15\end{array}$ & $\begin{array}{l}2.66 \\
3.53\end{array}$ & $\begin{array}{l}1.66 \\
2.85\end{array}$ & $\begin{array}{l}2.10 \\
1.00\end{array}$ \\
\hline
\end{tabular}

was not as pronounced. These results provide general, though equivocal, support for the hypothesis that Ss aroused as a result of interruption would be more influenced in their ratings of emotion by the social context than would the nonaroused Ss.

\section{DISCUSSION}

The results indicate trends which support the hypothesis of the study and warrant further consideration and replication. Mandler's (1964) proposition that arousal results from the interruption of an organized response has been substantiated. All experimental Ss produced the criterion index of arousal. There is the possibility that the increase in heart rate reflects the experience of increasing difficulty in arriving at a solution. However, such an explanation could be interpreted as a concomittant of interruption. The possibility does warrant investigation, however. The experiment provides some evidence of the validity of Schachter's (1964) hypothesis that arousal can be differentially manipulated to provide different emotional experience. The data show that the way Ss label their arousal does have something to do with the social situation to which they were exposed.

\section{REFERENCES}

MANDLER, G. The interruption of behavior. In D. Levine (Ed.), Nebraska symposium on motivation 1964. Lincoln: University of Nebraska Press, 1964. Pp. 163-219.

SCHACHTER, S. The interaction of cognitive and physiological determinants of emotional state. In L. Berk owitz (Ed.), Aduances in experimental social psychology. New York: Academic Press, 1964.

\section{CURRENT LITERATURE ON SOCIAL PROCESSES}

ALLEN, B. P. (Western Illinois University, Macomb, Ill. 61455). Social distance reactions to black and white communicators: $A$ replication of an investigation in support of belief congruence theory. Psychonomic Science, 1971, 22,344 .

BANIKIOTES, P. G. (University of Notre Dame, Notre Dame, Ind. 46556). Interpersonal attraction, topic importance, and proportion of item agreements. Psychonomic Science, 1971, 22, 353-354.

BROWN, R., SMITH, R. B., III, \& TEDESCHI, J. T. (State University of New York at Albany, Albany, N.Y. 12203). Impressions of a promisor after social deprivation or satiation. Psychonomic Science, $1971,23,135-136$.

BURRON, B. F. (University of Western Ontario, London, Ontario, Canada), CARLSON, K. A., GETTY, G. R., \& JACKSON, D. N. The effects of informational characteristics on the perception of real and hypothetical target persons. Psychonomic Science, 1971, 23, 145-147.

CRIDDLE, W. D. (University of British Columbia, Vancouver 8, British Columbia, Canada). The physical presence of other individuals as a factor in social facilitation. Psychonomic Science, 1971, 22, 229-230.

DABBS, J. M., JR. (Georgia State University, Atlanta, Ga. 30303). Physical closeness and negative feelings. Psychonomic Science, $1971,23,141-143$.

GOUAUX, C. (University of Texas Southwestern Medical School, Dallas, Tex. 75235), \& GOUAUX, $S$. $M$. The influence of induced affective states on the effectiveness of social and nonsocial reinforcers in an instrumental learning task. Psychonomic Science, 1971, 22, 341.343.

HENLEY, N. M. (University of Maryland, Baltimore County, Md. 21228), \& HORSFALL, R. B. Learning mixed social structures. Psychonomic Science, 1971, 23, 158-160.

HEWITT, J. (University of Missouri-Kansas City, Kansas City, Mo. 64110). Interpersonal attraction as a function of the type of favorable and unfavorable evaluation. Psychonomic Science, $1971,22,197-198$.

JACKSON, L. A. (University of Florida, Gainesville, Fla. 32601), \& MASCARO, G. F. Interpersonal attraction as a function of attitude similarity dissimilarity and attitude extremity. Psychonomic Science,
1971, 23, 187-188.

MARGULIS, S. T. (University of Florida, Gainesville, Fla. 32601), COSTANZO, P. R., \& KLEIN, A. L. Impression change and favorableness of first impressions: $A$ study of population and of commitment effects. Psychonomic Science, 1971, 22, 318-320.

McDANIEL, J. W. (Adrian College, Adrian, Mich. 49221), O'NEAL, E., \& FOX, E. S. Magnitude of retaliation as a function of the similarity of available responses to those employed by attacker. Psychonomic Science, 1971, 22, 215-217.

PHILLIPS, J. L. (Michigan State University, East Lansing, Mich. 48823), ARONOFF, J., \& MESSÉ, L. Sex and psychological need in triadic bargaining. Psychonomic Science, 1971, 22, 329-331.

ROSEN, B. (Graduate School of Business Administration, University of North Carolina, Chapel Hill, N.C. 27514). Evaluation of help by a potential recipient. Psychonomic Science, 1971, 23, 269-271.

TESSER, A. (University of Georgia, Athens, Ga. 30601), \& HAIGLER, D. Source and concept evaluation as determinants of inferred assertions. Psychonomic Science, 1971, 22, 369-371. 